\title{
RELATION BETWEEN PHYSICAL SPATIAL ORDER OF SETTLEMENT WITH BATAK TOBA SOCIETY'S KIN RELATIONSHIP \\ STUDY OBJECT: HUTA GINJANG VILLAGE, SIANJUR MULA-MULA SUB-DISTRICT
}

\author{
${ }^{1}$ Grace Mananda Hutabarat. ${ }^{2}$ Dr. Ir. Rumiati R. Tobing, M.T. \\ ${ }^{1}$ Student in the Bachelor's (S-1) Study Program in Architecture \\ at Parahyangan Catholic University \\ ${ }^{2}$ Senior lecturer in the Bachelor's (S-1) Study Program in Architecture \\ at Parahyangan Catholic University
}

\begin{abstract}
Batak Toba tribe is an ethnic group that still holds tradition as an identity that distinguish them from other ethnic groups in Indonesia. Part of the culture that strongly influences society's daily life is the kinship, as can be seen with the usage of family name and the philosophy of Dalihan na Tolu, which regulates attitudes and behaviors among society. Aside from the kinship, the traditional architecture is also a cultural identity of Batak Toba tribe, ranging from the order of settlements to organization of space in each dwelling.

The research aims to study the physical spatial order of the settlements as a consequence of Batak Toba kinship system, to see the relation between settlement's physical spatial order with the clan system and the philosophy of Dalihan na Tolu, and lastly to see the effect of modernization in the development of Batak Toba settlements.

Huta Ginjang Village in Sianjur Mula-mula is an indigenous village that still holds Batak Toba tradition and culture. Residents are mostly from the Sagala clan and originated from one ancestor. Each house is inhabited by one nuclear family and the collection of several dwellings in a certain order forms a settlement that still knows the kinship of one another. Huta Ginjang Village consists of eight cluster of settlements that still have relation to each other, forming a small clan group.

Data on the spatial physical order of the settlements in Huta Ginjang Village and the society's kin relationship are obtained from literature studies, direct observation in the object of study, and interview with the villagers. The obtained data were analyzed qualitatively by using the relation theory in architecture.

The result of the research shows the undeniable relation between physical spatial order of settlement in Huta Ginjang Village with the society's kin relationship, either on the village, huta, or on the dwelling scale. One of the relation can be seen in the absence of hierarchy in dwelling placement, as the principle of the Dalihan na Tolu has no hierarchy between each of the components. The relation with the kin relationship cannot be seen from each of the building's typology, because there are no special features that distinguishes each of the kinship groups.
\end{abstract}

Key Words: relation, physical spatial order, kin relationships, Huta Ginjang Village

\section{RELASI TATANAN FISIK SPASIAL PERMUKIMAN DENGAN HUBUNGAN KEKERABATAN SUKU BATAK TOBA OBJEK STUDI: DESA HUTA GINJANG, KEC. SIANJUR MULA-MULA}

\author{
${ }^{1}$ Grace Mananda Hutabarat. ${ }^{2}$ Dr. Ir. Rumiati R. Tobing, M.T. \\ ${ }^{1}$ Mahasiswi S1 Program Studi Arsitektur Universitas Katolik Parahyangan \\ ${ }^{2}$ Dosen Pembimbing S1 Program Studi Arsitektur Universitas Katolik Parahyangan
}

\begin{abstract}
Abstrak- Suku Batak Toba memegang teguh kebudayaan sebagai identitas yang membedakannya dari suku lain di Indonesia. Kebudayaan yang paling mempengaruhi kehidupan sehari-hari masyarakat Batak Toba adalah hubungan kekerabatan, tertuang dalam sistem marga dan falsafah Dalihan na Tolu, yang mengatur cara bersikap
\end{abstract}

\footnotetext{
${ }^{1}$ Corresponding Author: gracemananda@gmail.com
} 
dan berperilaku dalam masyarakat. Selain hubungan kekerabatan, wujud arsitektur tradisional juga menjadi identitas budaya suku Batak Toba, baik dari penataan permukiman hingga organisasi ruang dalam rumah tinggal.

Penelitian ini bertujuan untuk mengetahui bagaimana tatanan fisik spasial permukiman yang terbentuk akibat hubungan kekerabatan suku Batak Toba, melihat bagaimana relasi antara tatanan fisik spasial dengan sistem marga dan sistem Dalihan na Tolu, serta melihat pengaruh modernisasi terhadap perkembangan arsitektur permukiman Batak Toba.

Desa Huta Ginjang di Kecamatan Sianjur Mula-mula merupakan desa adat yang masih memegang tradisi dan kebudayaan suku Batak Toba. Warga desa ini sebagian besar bermarga Sagala dan masih berasal dari satu nenek moyang. Setiap rumah tinggal dihuni oleh keluarga inti dan kumpulan beberapa rumah tinggal dalam tatanan tertentu membentuk sebuah permukiman yang masih mengenal kekerabatan satu sama lain. Desa Huta Ginjang terdiri atas delapan kelompok permukiman yang masih memiliki kekerabatan, yaitu sebagai kelompok klen kecil.

Data mengenai tatanan fisik spasial permukiman di Desa Huta Ginjang dan hubungan kekerabatan masyarakat setempat diperoleh melalui studi kepustakaan, observasi di lapangan, dan wawancara dengan warga Desa Huta Ginjang. Data yang diperoleh diolah secara kualitatif dengan menggunakan teori relasi dalam arsitektur.

Hasil penelitian menunjukkan adanya relasi antara tatanan fisik spasial permukiman dengan hubungan kekerabatan masyarakat Batak Toba, baik pada skala desa, kampung, dan rumah tinggal. Relasi tersebut salah satunya dapat dilihat pada tatanan rumah tinggal yang tidak memiliki hierarki perletakan, sebagaimana prinsip kekerabatan Dalihan na Tolu tidak memiliki hierarki antar komponen. Relasi dengan hubungan kekerabatan tidak dapat dilihat melalui tipologi bangunan yang ada dalam permukiman, karena tidak adanya ciri khas yang membedakan satu kelompok kekerabatan dengan kelompok lainnya pada wujud fisik bangunan.

Kata Kunci: relasi, tatanan fisik spasial, hubungan kekerabatan, Desa Huta Ginjang

\section{PENDAHULUAN}

Bangsa Indonesia terdiri dari banyak suku yang memiliki budaya dan adat istiadat masing-masing. Salah satu suku di Indonesia yang sangat kuat dalam memegang adat istiadat adalah suku Batak Toba yang berada di Provinsi Sumatera Utara. Suku Batak Toba sampai saat ini masih memegang teguh kebudayaan yang sudah diwariskan secara turun temurun dari leluhur. Salah satu bentuk kebudayaan masyarakat Batak Toba dapat dilihat dalam adat istiadat, kehidupan sehari-hari, ritual-ritual perayaan kelahiran, pernikahan, hingga kematian, bahkan turut mempengaruhi kegiatan keagamaan.

Sistem kemasyarakatan dan organisasi sosial merupakan salah satu dari tujuh unsur kebudayaan $^{2}$, meliputi kekerabatan, asosiasi, sistem kenegaraan, sistem kesatuan hidup, dan perkumpulan. Kekerabatan adalah hubungan antar orang yang memiliki kesamaan silsilah, keturunan, maupun adat, baik secara biologis, sosial, maupun budaya. Bagian dari kebudayaan Batak Toba yang memiliki arti penting dalam kehidupan masyarakatnya adalah hubungan kekerabatannya. Hubungan kekerabatan dalam suku Batak Toba tertuang ke dalam falsafah Dalihan na Tolu dan sistem marga.

Salah satu daerah yang masih memegang kuat adat istiadat dan tradisi suku Batak Toba adalah Desa Huta Ginjang, Kecamatan Sianjur Mula-mula, Kabupaten Samosir. Sianjur Mulamula merupakan permukiman pertama yang dibangun oleh leluhur suku Batak Toba. Ke mana pun orang Batak merantau, mereka akan menyebut Sianjur Mula-mula sebagai bona pasogit atau kampung halaman.

Desa Huta Ginjang memiliki potensi budaya yang kuat, dibuktikan dengan masih adanya rumah-rumah dengan arsitektur tradisional dan situs prasejarah di Pusuk Buhit. Kampung adat di Desa Huta Ginjang masih memiliki tradisi-tradisi permukiman yang diturunkan dari leluhur, meskipun sudah memiliki perkembangan akibat masuknya budaya modern. Penelitian ini melihat penataan fisik spasial di Desa Huta Ginjang, baik pada permukiman, lingkungan, maupun pada masing-masing rumah tinggal, dalam kaitannya dengan hubungan kekerabatan masyarakat yang menempatinya.

\footnotetext{
${ }^{2}$ KOENTJARANINGRAT. 1996. Pengantar Ilmu Antropologi: Jilid I. Jakarta: Rineka Cipta.
} 
Sistem kekerabatan masyarakat suku Batak Toba memiliki relasi dengan bentuk arsitektur tradisional, yaitu yang tercermin dalam tatanan permukiman dan bentuk fisik bangunan rumah tinggal. Berdasarkan permasalahan yang telah dijabarkan, masalah dalam penelitian adalah sebagai berikut:

1) Bagaimana tatanan fisik spasial permukiman yang terbentuk akibat hubungan kekerabatan suku Batak Toba?

2) Bagaimana relasi antara tatanan fisik spasial permukiman suku Batak Toba dengan sistem marga?

3) Bagaimana relasi antara tatanan fisik spasial permukiman suku Batak Toba dengan sistem kemasyarakatan Dalihan na Tolu?

4) Bagaimana pengaruh modernisasi terhadap perkembangan arsitektur permukiman suku Batak Toba?

Penelitian ini dilakukan dengan tujuan untuk mengetahui tatanan fisik spasial permukiman yang terbentuk akibat dari hubungan kekerabatan masyarakat suku Batak Toba, mengetahui relasi antara tatanan fisik spasial permukiman di Desa Huta Ginjang degan sistem marga dan sistem kemasyarakatan Dalihan na Tolu, serta mempelajari pengaruh modernisasi terhadap perkembangan arsitektur permukiman di Desa Huta Ginjang. Hasil penelitian ini bermanfaat untuk memperluas wawasan arsitektur tradisional di Indonesia, khususnya arsitektur tradisional suku Batak Toba dan memberikan informasi mengenai kondisi permukiman di Desa Huta Ginjang.

\section{KAJIAN TEORI}

\subsection{RELASI DALAM ARSITEKTUR}

Relasi dalam arsitektur adalah keterikatan antara aspek-aspek kertaji (tangible) dan akertaji (intangible) dari arsitektur. Aspek kertaji adalah aspek fisik yang nyata, dapat dilihat dan dirasakan, seperti: bentuk, material, dan ruang. Aspek akertaji adalah aspek yang sifatnya lebih abstrak, seperti fungsi dan kebudayaan. Ruang dalam arsitektur dapat menunjukkan nilainilai absktrak, seperti kebudayaan, nilai sosial, kebiasaan, dan ritual adat istiadat. Relasi dalam arsitektur dapat digolongkan ke dalam tiga kelompok utama, yaitu relasi bentuk, relasi fungsi, dan relasi budaya.

Relasi bentuk dalam arsitektur melihat pada bentuk tiga dimensi atau bentuk spasial, yaitu melihat bagaimana dua atau lebih elemen dan atau ruang saling berhubungan. Dalam konteks bentuk arsitektural, relasi terfokus pada pola penataan dan distribusi elemen-elemen arsitektural. Beberapa relasi bentuk dalam arsitektur antara lain $^{3}$ :

Tabel 1. Jenis-jenis Relasi Bentuk dalam Arsitektur

\begin{tabular}{ll}
\multicolumn{1}{c}{ Relasi Bentuk } & Pengertian \\
\hline Relasi kedekatan & Relasi penataan di mana elemen-elemen yang \\
(proximity) & saling berdekatan satu sama lain membentuk \\
kelompok atau cluster.
\end{tabular}

\footnotetext{
${ }^{3}$ NORBERG-SCHULZ, Christian. 1966. Intentions in Architecture. Massachusetts: MIT Press.
} 


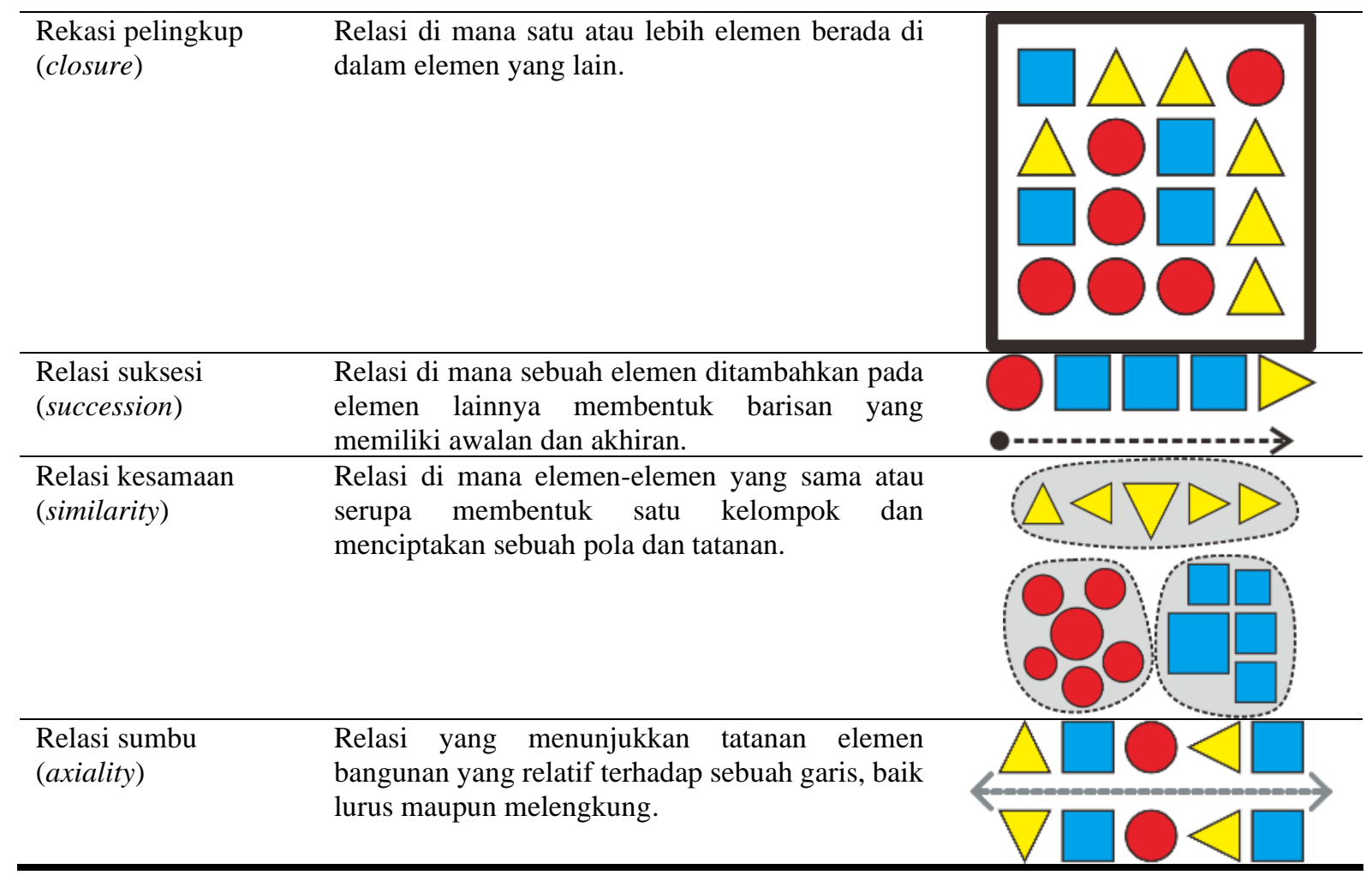

Relasi fungsi dalam arsitektur merujuk pada empat tugas bangunan ${ }^{4}$, yaitu:

1) Fungsi kontrol fisik (physical control), yaitu fungsi bangunan untuk mengendalikan kondisi fisik lingkungan, mulai dari iklim, kondisi geografis, hingga perlindungan dari binatang buas.

2) Wadah fungsional (functional frame), yaitu fungsi arsitektur yang harus dapat mengakomodasi kebutuhan aktivitas, pengguna ruang, dan kebutuhan ruang gerak.

3) Status sosial (social milieu), yaitu fungsi bangunan sebagai penunjuk struktur sosial dalam masyarakat, seperti status, peran, dan kelompok dalam masyarakat.

4) Simbol kebudayaan (cultural symbolization), yaitu fungsi bangunan sebagai produk kebudayaan yang mengandung nilai, gagasan filosofis, aturan, dan moral yang dipegang teguh dalam masyarakat.

Arsitektur merupakan jiwa dari kebudayaan, yang dapat dilihat dalam bentuk ruang spasial maupun fisik strukturalnya ${ }^{5}$. Bentuk arsitektur, khususnya pada permukiman dan rumah tinggal, merupakan sebuah fenomena budaya, sehingga bentuk dan tatanannya banyak dipengaruhi oleh kebudayaan setempat. Faktor utama yang menentukan bentuk arsitektur tradisional adalah faktor sosial-budaya, yang meliputi kepercayaan, keluarga dan struktur marga, organisasi, hingga interaksi sosial antar individu dalam masyarakat ${ }^{6}$. Bentukan arsitektur tradisional merupakan tujuan dan harapan sekelompok masyarakat akan sebuah lingkungan yang dianggap ideal.

\footnotetext{
${ }^{4}$ NORBERG-SCHULZ, Christian. 1966. Intentions in Architecture. Massachusetts: MIT Press.

${ }^{5}$ HENDRIX, John. 2012. Architecture as the Psyche of a Culture. (Dalam Emmons, Paul., Hendrix, John., \& Lomholt, Jane (eds.), The Cultural Role of Architecture. Oxon: Routledge. hal. 208-216.)

${ }^{6}$ RAPOPORT, Amos. House Form and Culture. Englewood Cliffs, N.J.: Prentice-Hall, Inc.
} 


\subsection{HUBUNGAN KEKERABATAN DALAM MASYARAKAT SUKU BATAK TOBA}

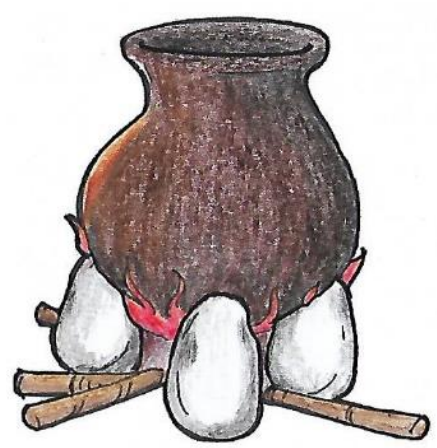

Figur 1. Masyarakat Batak Toba dianalogikan sebagai tungku batu tiga kaki

Hubungan kekerabatan dalam suku Batak Toba tertuang ke dalam falsafah Dalihan na Tolu dan sistem marga. Dalihan na Tolu, yang artinya tungku tiga kaki, adalah sebuah sistem kemasyarakatan yang sangat penting karena mengajarkan struktur kekerabatan dalam masyarakat. Falsafah ini digunakan sebagai dasar dan pegangan berperilaku dan berinteraksi dalam masyarakat, serta menunjukkan kedudukan dalam upacara adat. Sistem kemasyarakatan Dalihan na Tolu ini terdiri atas tiga komponen yang tidak dapat dipisahkan satu sama lain, yaitu hula-hula, dongan tubu, dan boru? .

Hula-hula memiliki kedudukan tertinggi dan paling dihormati, sehingga pihak lain harus bersikap tunduk dan hormat. Kelompok hula-hula berasal dari pihak keluarga istri sebagai pemberi anak perempuan. Dongan tubu adalah kelompok yang berasal dari satu marga, yang setiap anggotanya harus saling menjaga persaudaraan dan menghindari perselisihan. Boru adalah kelompok yang paling rendah kedudukannya yang harus dikasihi tanpa pamrih oleh anggota kelompok yang lain, berasal dari kelompok anak perempuan dalam suatu marga beserta dengan suaminya. Sistem kekerabatan dalam suku Batak Toba ini bersifat kontekstual, di mana semua masyarakat Batak pasti pernah menjadi hula-hula, menjadi dongan tubu, ataupun menjadi boru.

Suku Batak Toba identik dengan penggunaan marga. Marga dalam suku Batak Toba adalah nama leluhur induk dari silsilah kekerabatan. Marga Batak Toba berasal dari keturunan leluhur yang disebut Si Raja Batak. Marga adalah kelompok kekerabatan yang bersifat eksogam, yang berarti orang yang berasal dari satu marga tidak boleh saling mengawini. Marga merupakan hubungan kekerabatan berdasarkan genealogis, yaitu diturunkan menurut garis keturunan ayah (patrilineal). Sistem marga memiliki dampak sosial dalam menentukan status dan menjadi ukuran bagaimana bersikap dan berperilaku terhadap orang lain.

\subsection{PERMUKIMAN TRADISIONAL BATAK TOBA}

Selain adat istiadatnya, kebudayaan suku Batak Toba dapat dilihat dalam bentuk arsitektur tradisional. Arsitektur tradisional Batak Toba dapat dilihat dari pola perkampungan dan bentuk fisik bangunan rumah tinggal masyarakatnya.

Permukiman tradisional Batak Toba disebut sebagai huta, dalam bahasa Indonesia berarti kampung. Huta tradisional Batak Toba pada umumnya berbentuk persegi dan dikelilingi oleh benteng yang tinggi dan tebal. Di bagian dalam benteng terdapat dua baris bangunan yang

\footnotetext{
${ }^{7}$ SANGTI, Batara. 1978. Sejarah Batak. Balige: Karl Sianipar Company.
} 
saling berhadapan dan mengapit sebuah halaman yang luas. Salah satu baris terdiri atas rumah tinggal (disebut ruma atau jabu) dan baris lainnya terdiri atas lumbung (disebut sopo) ) $^{8,9,10}$.

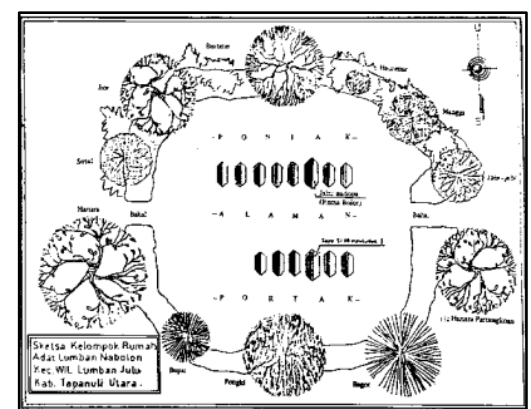

Figur 2. Pola penataan huta Batak Toba (Sumber: Napitupulu, 1986)

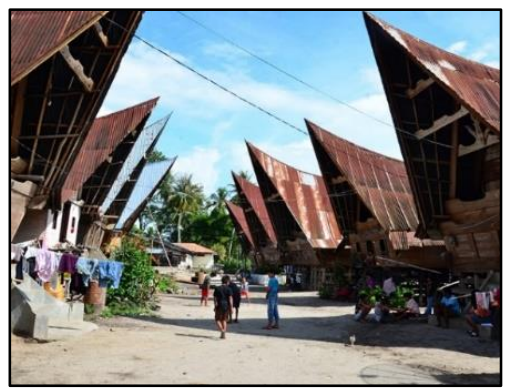

Figur 3. Bangunan ditata berbanjar dua dan saling berhadapan

(Sumber: travel.kompas.com)

Sebuah huta Batak Toba dihuni oleh kerabat semarga yang berasal dari satu oтри (nenek moyang). Penduduk huta pun berkembang dengan masuknya marga-marga boru dari pemuda-pemuda yang menikahi anak perempuan dalam marga tersebut. Sebuah huta dihuni oleh beberapa keluarga yang berasal dari ikatan darah, yaitu keluarga yang berasal dari garis keturunan seorang nenek moyang, dan juga ikatan perkawinan, yaitu hubungan antara hulahula dengan boru-nya yang merupakan konsekuensi dari perkawinan.

Warga yang menempati huta digolongkan ke dalam dua kelompok marga, yaitu kelompok marga-raja dan marga-boru ${ }^{11}$. Marga-raja adalah kelompok marga yang menjadi perintis dibangunnya sebuah permukiman. Kelompok marga-raja memiliki hak dan wewenang untuk mengelola tanah dalam wilayah kampung. Selain kelompok marga pionir, terdapat pula marga-boru dan marga-pendatang. Kelompok marga-boru berasal dari pemuda yang menikahi putri dari marga-raja, juga memiliki hak mengelola tanah yang diberikan oleh mertuanya.

\section{METODA PENELITIAN}

Metode penelitian kualitatif digunakan untuk menjawab pertanyaan penelitian. Data yang dikumpulkan di lapangan dan analisis terhadap data tersebut disajikan dalam bentuk naratif deskriptif secara rinci dan mendalam mengenai topik penelitian. Fenomena yang terjadi pada objek penelitian dipelajari secara mendalam, untuk melihat dan mempelajari latar belakang, keadaan, dan peristiwa yang terjadi.

Pengumpulan data dilakukan melalui tiga cara, yaitu: studi kepustakaan, observasi dan pengukuran di lapangan, serta wawancara. Studi kepustakaan mengenai objek studi dikumpulkan dari buku, jurnal, dan penelitian mengenai Desa Huta Ginjang yang pernah dilakukan sebelumnya. Data-data di lapangan, baik yang bersifat fisik maupun non fisik diperoleh dengan melakukan observasi dan pengukuran langsung di lapangan. Wawancara dilakukan dengan Bapak Gisal Sagala (usia 68 tahun) sebagai Raja Bius Desa Huta Ginjang dan Raja Tano Kampung Lumban Godang.

\footnotetext{
${ }^{8}$ NAPITUPULU, S.P., et al. 1986. Arsitektur Tradisional Daerah Sumatera Utara. Jakarta: Departemen Pendidikan dan Kebudayaan.

${ }^{9}$ DE BOER, D.W. 1920. Het Toba Bataksche Huis. (Dalam Sargeant, G.T. \& Saleh, R., Traditional Buildings of Indonesia Volume I: Batak Toba. Bandung: United Nations - Regional Housing Centre - Ecafe. hal. 31-41.) 10 SARGEANT, G.T. \& SALEH, R. 1973. Traditional Buildings of Indonesia Volume I: Batak Toba. Bandung: United Nations - Regional Housing Centre - Ecafe.

11 SITUMORANG, Sitor. 2009. Toba Na Sae. Jakarta: Komunitas Bambu.
} 
Populasi penelitian adalah seluruh kelompok permukiman yang ada di Desa Huta Ginjang, yaitu Kampung Lumban Godang, Sosor, Talun, Lumban Buntu, Simanampang, Aek Mual, Sibuntuon, Nahulhul, dan Pandulongan. Sampel penelitian yang digunakan adalah Kampung Lumban Godang dan Kampung Sosor, yang dipilih untuk memfokuskan pengamatan mengenai relasi hubungan kekerabatan dengan tatanan fisik spasial permukiman tradisional Batak Toba serta pengaruh modernisasi terhadap perkembangan arsitekturnya.

\subsection{OBYEK DAN METODE}

Desa Huta Ginjang berada di wilayah perbukitan dengan ketinggian 1340-1400 meter di atas permukaan laut. Desa Huta Ginjang berbatasan dengan Danau Toba di sebelah utara, Kecamatan Pangururan di sebelah timur, Gunung Pusuk Buhit di sebelah selatan, dan Desa Ginolat di sebelah barat. Desa ini merupakan kumpulan dari permukiman yang membentuk cluster memiliki tatanan linear. Setiap cluster terdiri atas 10 - 25 rumah tinggal dan membentuk sebuah huta atau kampung. Wilayah perbukitan Desa Huta Ginjang terdiri atas delapan buah cluster, yaitu: Kampung Lumban Godang, Sosor, Talun, Lumban Buntu, Simanampang, Aek Mual, Sibuntuon, dan Nahulhul.

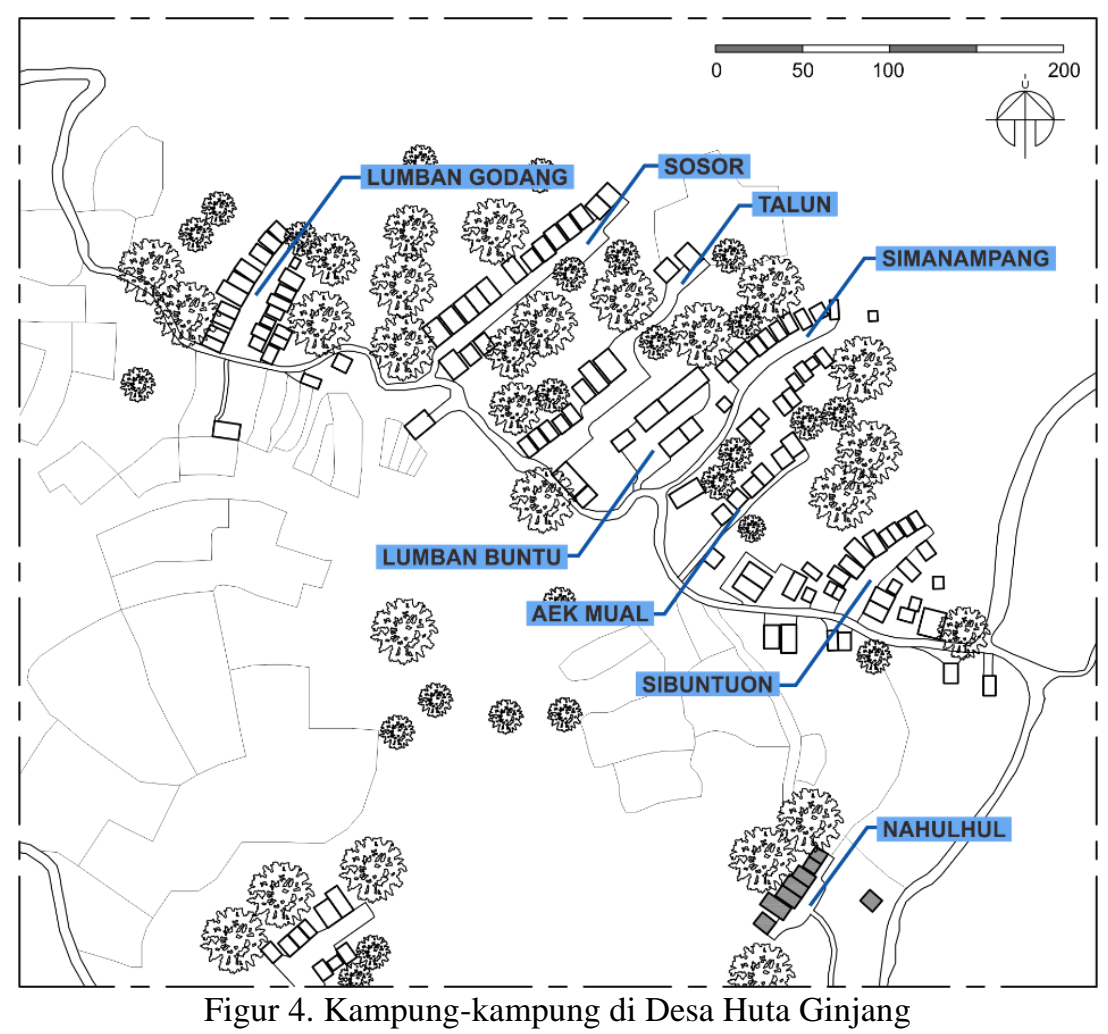

Mayoritas penduduk Desa Huta Ginjang berasal dari marga Sagala. Marga Sagala ini merupakan marga dari pendiri permukiman pertama di Desa Huta Ginjang, yaitu Op. Pahoek Tuan Rikkor Sagala. Berdasarkan pengelompokan marga penghuni kampung, marga Sagala termasuk ke dalam kelompok marga-raja, yaitu marga keturunan pendiri kampung. Marga ini juga merupakan marga partano, yang berarti pemilik tanah. Sistem kekerabatan marga Sagala di Desa Huta Ginjang terpisah dari sistem kekerabatan marga Sagala di daerah lain. Hal ini menunjukkan prinsip teritorial dalam sistem marga Batak Toba, yang membentuk sebuah localized clan di Desa Huta Ginjang ${ }^{12}$.

Marga-marga lainnya yang menempati Desa Huta Ginjang antara lain: Siboro, Sigiro, Simarmata, Simanjorang, Sinaga, Sitanggang, Limbong, Purba, Siallagan, Malau, dan

12 SITUMORANG, Sitor. 2009. Toba Na Sae. Jakarta: Komunitas Bambu. 
Situmorang. Marga-marga tersebut merupakan marga dari pemuda yang menikahi putri boru Sagala, sehingga termasuk ke dalam klasifikasi marga-boru.

Elemen fisik spasial pembentuk ruang pada masing-masing kampung di Desa Huta Ginjang antara lain: bangunan rumah tinggal, halaman, dan sirkulasi.

Rumah tinggal. Bangunan rumah tinggal di setiap kampung dapat digolongkan ke dalam 3 tipe utama, yaitu jabu bolon, rumah angkola, dan rumah modern.

Tabel 2. Tipe-tipe Rumah Tinggal di Desa Huta Ginjang

\begin{tabular}{|c|c|c|c|}
\hline Ciri-ciri & Jabu Bolon & Rumah Angkola & Rumah Modern \\
\hline Atap & $\begin{array}{l}\text { Atap dominan dan } \\
\text { berbentuk melengkung }\end{array}$ & $\begin{array}{l}\text { Atap dominan dan } \\
\text { berbentuk melengkung }\end{array}$ & $\begin{array}{l}\text { Atap sederhana, berbentuk } \\
\text { pelana ataupun perisai }\end{array}$ \\
\hline Tipologi rumah & Panggung & Panggung & Panggung dan landed \\
\hline Wujud fisik & $\begin{array}{l}\text { Dinding miring dengan } \\
\text { tangga masuk yang } \\
\text { tersembunyi }\end{array}$ & $\begin{array}{l}\text { Dinding lurus dengan } \\
\text { tangga masuk berada di } \\
\text { muka bangunan; } \\
\text { Fisik bangunan lebih } \\
\text { sederhana }\end{array}$ & $\begin{array}{l}\text { Dinding lurus dengan pintu } \\
\text { masuk berada di muka } \\
\text { bangunan; } \\
\text { Fisik bangunan sangat } \\
\text { sederhana }\end{array}$ \\
\hline Ornamen & $\begin{array}{l}\text { Papan kayu pada dinding } \\
\text { yang dipahat }\end{array}$ & Tidak ada & Tidak ada \\
\hline Material & Kayu dan atap seng & Kayu dan atap seng & $\begin{array}{l}\text { Kayu, pasangan bata, beton, } \\
\text { dan atap seng }\end{array}$ \\
\hline Contoh & 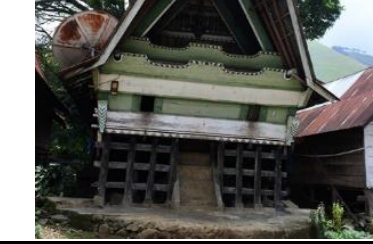 & & \\
\hline
\end{tabular}

Halaman kampung. Halaman kampung, atau disebut sebagai alaman, terbentang di sepanjang deret kampung dengan lebar mencapai 12 meter. Halaman kampung yang luas ini merupakan milik bersama warga, berfungsi untuk tempat bermain, tempat berkumpul, tempat menjemur hasil panen, dan dimanfaatkan sebagai sirkulasi dalam wilayah kampung.

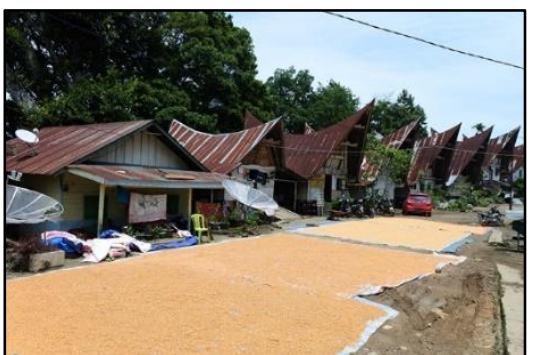

Figur 5. Halaman Kampung Lumban Godang

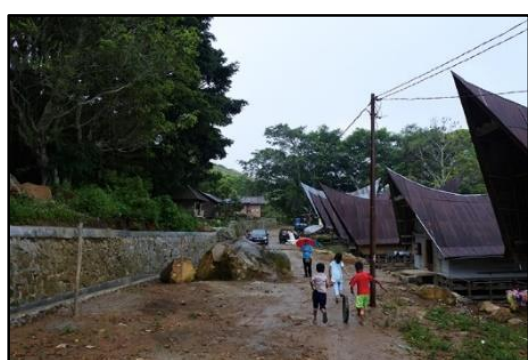

Figur 6. Halaman Kampung Sosor

Jalur sirkulasi antar kampung berfungsi sebagai jalur yang menghubungkan satu kampung dengan kampung lainnya. Jalur sirkulasi terbuat dari tanah berbatu dengan lebar 4 5 meter yang dapat dilalui oleh kendaraan bermotor, termasuk mobil. Jalan ini merupakan satusatunya akses masuk menuju ke masing-masing kampung. Sirkulasi di dalam kampung, baik pada Kampung Lumban Godang maupun Kampung Sosor, merupakan halaman kampung yang 
berada di sepanjang barisan kampung. Sirkulasi ini dapat dilalui oleh manusia dan kendaraan bermotor, dan dimanfaatkan juga sebagai ruang parkir.

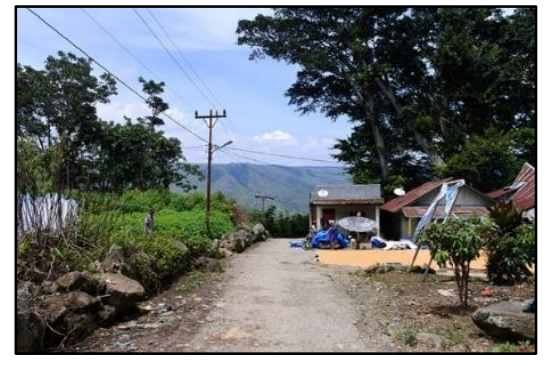

Figur 7. Sirkulasi penghubung antar kampung di Desa Huta Ginjang

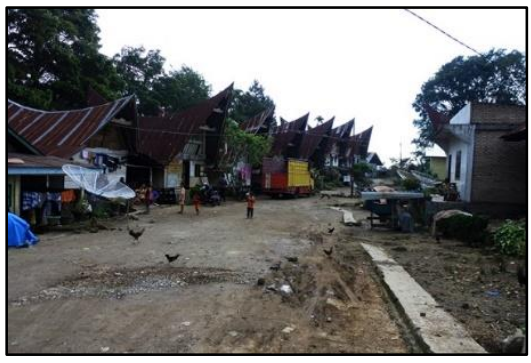

Figur 8. Halaman sebagai ruang sirkulasi pada masing-masing kampung

\section{ANALISA}

\subsection{SKALA DESA}

Cluster-cluster dalam Desa Huta Ginjang terbentuk karena relasi kedekatan (proximity), yaitu rumah tinggal yang memiliki jarak antar bangunan yang relatif kecil tanpa memperhatikan orientasi bangunan dan bentuk masing-masing elemennya. Aspek kedekatan antar kampung di Desa Huta Ginjang dipengaruhi oleh hubungan kekerabatan masyarakatnya.

Pembangunan Desa Huta Ginjang dari pembangunan permukiman di Kampung Lumban Godang. Pendiri permukiman ini bergelar Raja Bius di Desa Huta Ginjang dan Raja Tano di Kampung Lumban Godang. Ketika kampung ini penuh, satu atau lebih keluarga membuka permukiman yang baru di Kampung Sosor, dan perintisnya diberi gelar Raja Tano Kampung Sosor. Pembangunan kampung yang baru dipengaruhi oleh faktor ketersediaan lahan di wilayah masing-masing kampung. Fenomena pendirian kampung-kampung di Desa Huta Ginjang menunjukkan kampung yang saling berdekatan memiliki kekerabatan yang lebih erat.

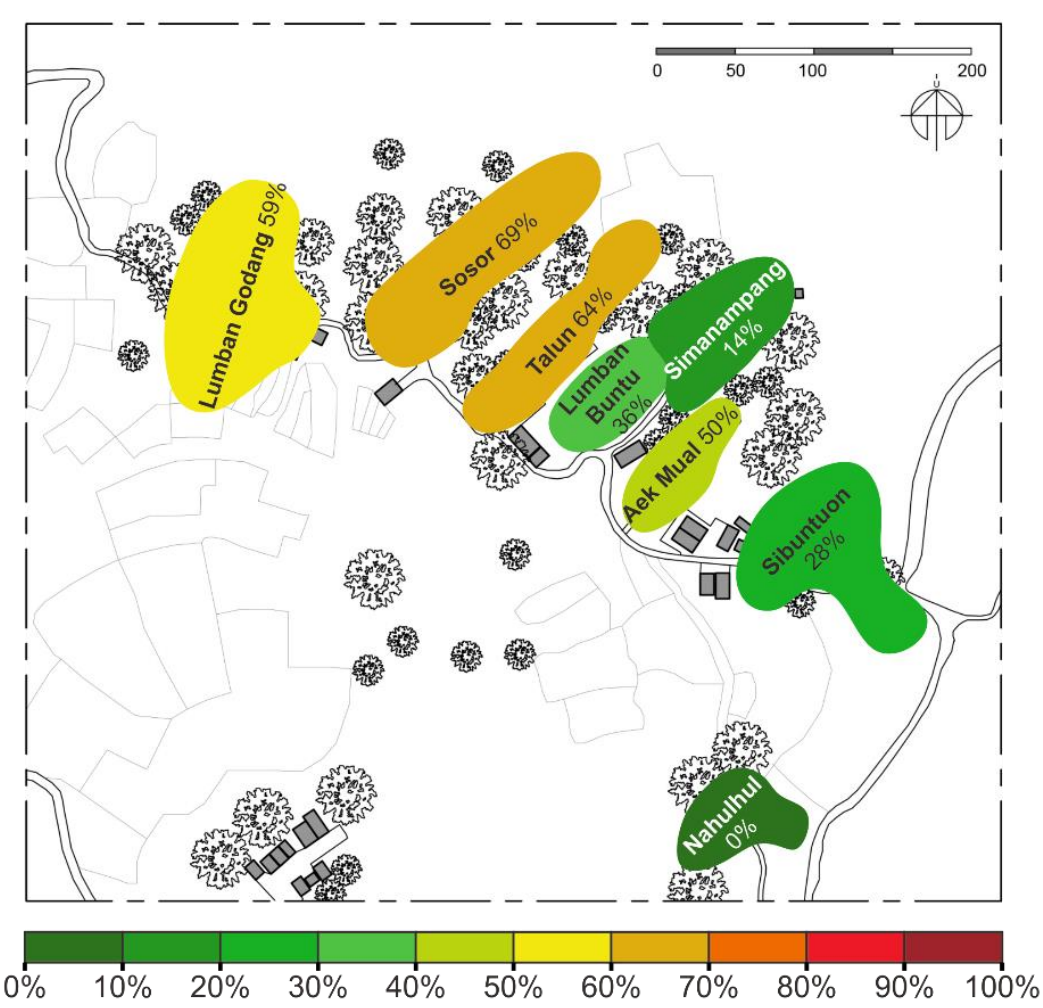


Figur 9. Persentase marga Sagala pada kampung-kampung di Desa Huta Ginjang

Figur 9 menunjukkan persentase marga Sagala yang menghuni masing-masing kampung. Kampung-kampung yang letaknya berdekatan dengan Kampung Lumban Godang sebagai kampung pertama memiliki penduduk bermarga Sagala yang relatif lebih banyak dibandingkan kampung yang posisinya lebih jauh. Kekerabatan di Desa Huta Ginjang ditunjukkaan dengan derajat kedekatan (proximity) antara sebuah kampung terhadap kampung induknya. Semakin dekat jarak antara kampung dengan kampung induk, semakin kuat hubungan kekerabatannya.

\subsection{SKALA KAMPUNG}

Prinsip-prinsip relasi kedekatan juga dapat dilihat dalam skala kampung di Desa Huta Ginjang. Rumah tinggal di kampung memiliki orientasi yang beragam, baik berhadapan maupun saling memunggungi. Bentuk rumah tinggal dalam deret kampung juga bervariasi, mulai dari bentuk tradisional dengan material kayu hingga rumah yang bentuknya yang lebih modern dengan material pasangan bata. Meskipun demikian, rumah-rumah ini tetap termasuk ke dalam satu cluster yang sama, karena memiliki jarak antar rumah tinggal yang relatif kecil.

Tatanan rumah tinggal di skala kampung menunjukkan relasi aksial (axiality), yaitu rumah-rumah yang berada dalam satu kelompok tersebut diorganisasikan relatif terhadap sebuah garis imajiner. Garis imajiner yang menjadi patokan penataan rumah tinggal adalah sebuah ruang terbuka yang merupakan halaman yang merupakan milik bersama warga kampung.

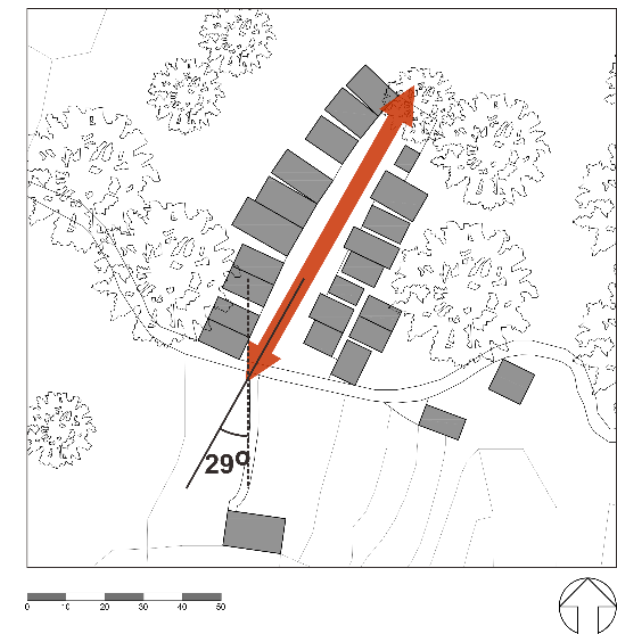

Figur 10. Relasi aksial di Kampung Lumban Godang

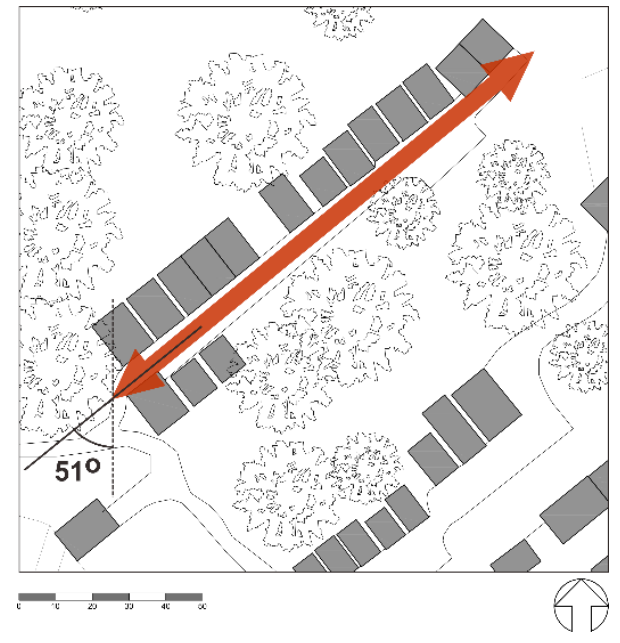

Figur 11. Relasi aksial di Kampung Sosor

Pusat Aktivitas. Pusat aktivitas warga kampung berada di alaman atau halaman kampung. Halaman kampung ini membentang di sepanjang barisan rumah tinggal, dan memiliki lebar rata-rata 8,8 - 12 meter. Halaman memiliki fungsi fisik-spasial profan, yaitu digunakan untuk kegiatan sehari-hari warga kampung, misalnya, bermain, menjemur hasil kebun, dan parkir kendaraan. Pada kesempatan khusus, halaman digunakan sebagai tempat berkumpul seluruh warga kampung, sehingga halaman ini pun memiliki fungsi sosial. Ruang terbuka ini juga dimanfaatkan untuk mengadakan pesta atau ritual adat, sehingga menunjukkan bahwa ruang ini pun memiliki fungsi sakral. 

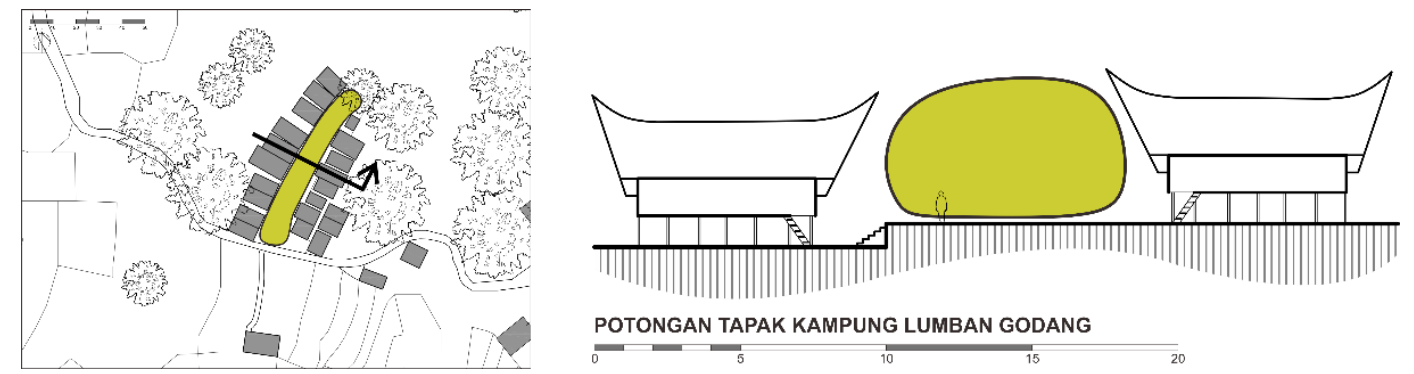

Figur 12. Halaman Kampung Lumban Godang
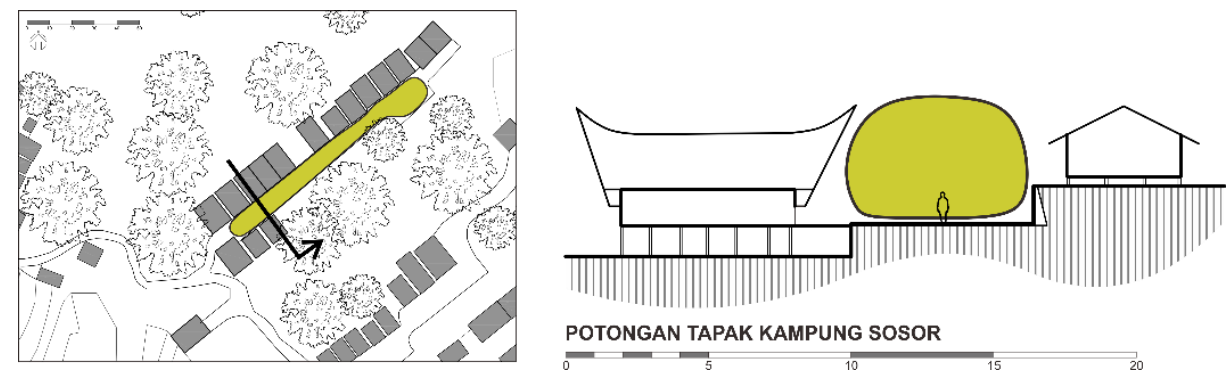

Figur 13. Halaman Kampung Sosor

Ruang terbuka ini dibentuk oleh deretan rumah tinggal di sisi kanan dan kirinya. Secara spasial dan fungsional, ruang terbuka ini berfungsi sebagai pengikat seluruh rumah yang ada di dalam wilayah kampung. Halaman di kampung memiliki kapasitas yang cukup untuk menampung aktivitas dari seluruh warga. Kapasitas ruang terbuka ini sesuai untuk fungsinya yang harus menampung warga kampung, khususnya pada acara-acara adat yang melibatkan seluruh warga.

Analisis Perkembangan Pembangunan Kampung. Analisis terhadap tipe fisik rumah tinggal di setiap kampung menunjukkan adanya periodisasi pembangunan di setiap kampung. Rumah-rumah dikelompokkan berdasarkan relasi kesamaan (similarity) menurut tipe jabu bolon, rumah angkola, rumah modern panggung, dan rumah modern landed. Titik awal pembangunan kampung berada di bagian tengah barisan rumah tinggal yang berorientasi menghadap ke arah situs sakral Gunung Pusuk Buhit. Rumah pertama yang dibangun di setiap kampung merupakan rumah milik pemimpin struktur adat yang bergelar Raja Tano. Rumahrumah berikutnya dibangun di seberangnya, dan sisi kanan atau kiri rumah yang pertama dibangun, bergerak ke arah ujung kampung.
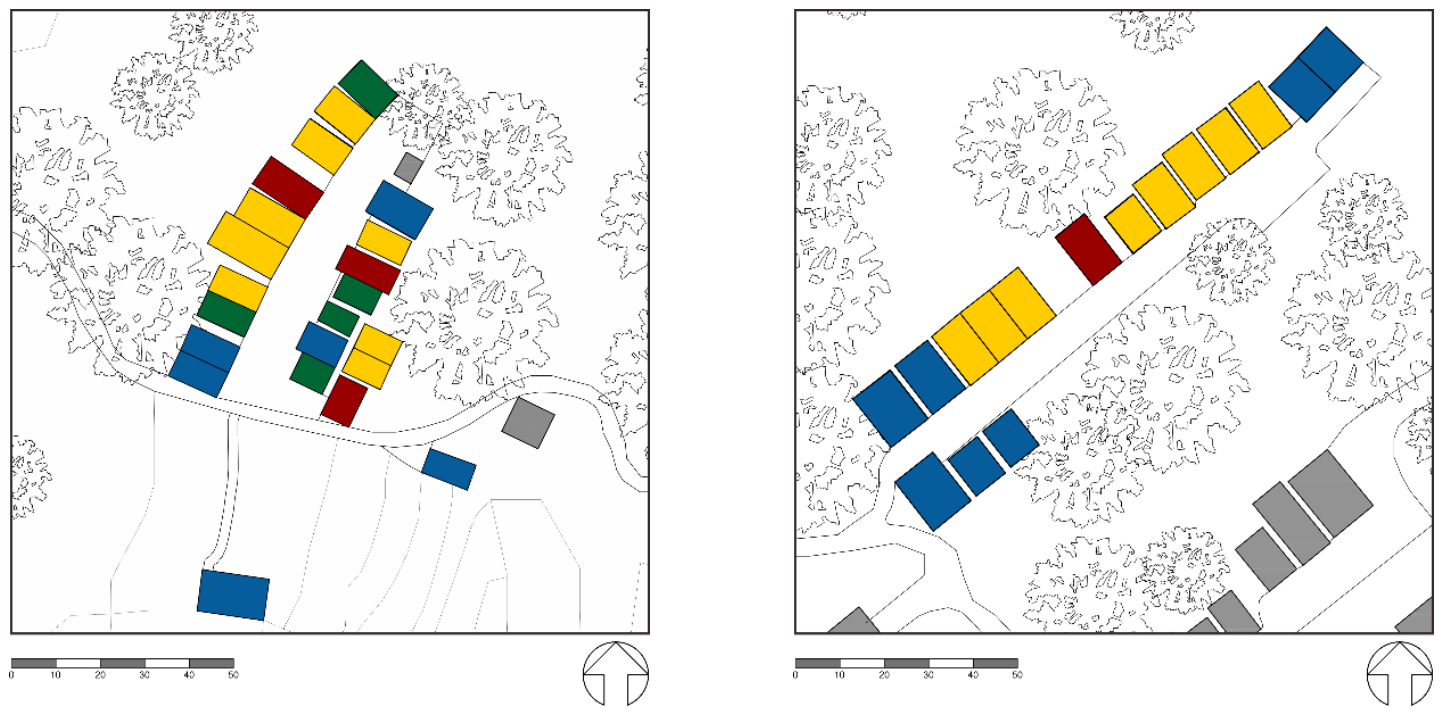
Figur 14. Pengelompokan rumah tinggal di Kampung Lumban Godang berdasarkan tipe fisik
Figur 15. Pengelompokan rumah tinggal di Kampung Sosor berdasarkan tipe fisik
Rumah Jabu Bolon

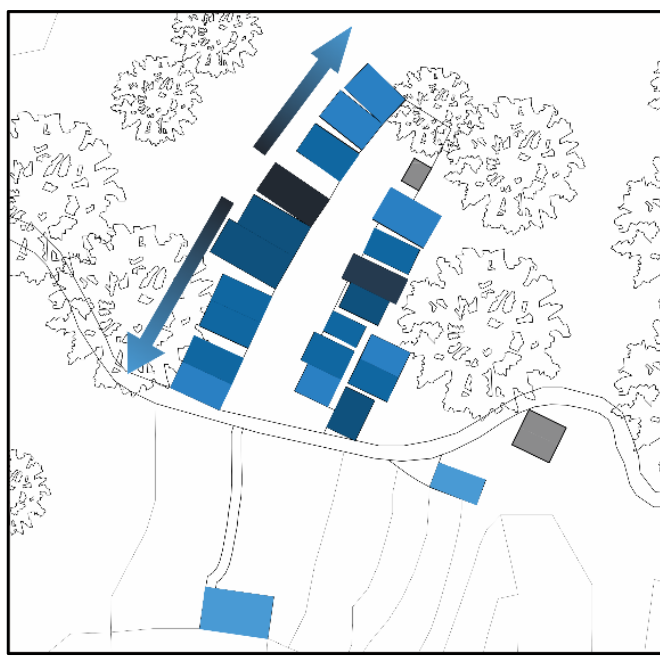

Figur 16. Arah perkembangan pembangunan di Kampung Lumban Godang
Rumah Modern Panggung $\quad$ Rumah Modern Landed

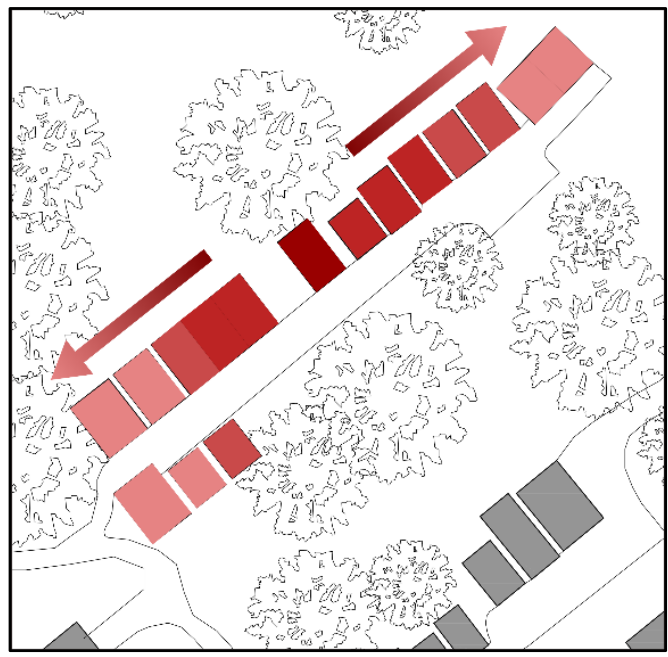

Figur 17. Arah perkembangan pembangunan di Kampung Sosor

Analisis terhadap tahapan pembangunan rumah tinggal di kedua kampung menunjukkan adanya keterkaitan antara jarak antar rumah tinggal dengan hubungan kekerabatan penghuninya. Rumah tinggal yang dijadikan patokan ukuran kedekatan adalah rumah Raja Tano sebagai rumah pertama yang dibangun di setiap kampung. Semakin dekat jarak sebuah rumah tinggal terhadap rumah Raja Tano, semakin erat hubungan kekerabatannya. Sebaliknya, semakin jauh jarak rumah tinggal terhadap rumah Raja Tano, maka semakin jauh atau renggang pula hubungan kekerabatannya. Dengan kata lain, semakin tengah posisi bangunan rumah tinggal, semakin dekat kekerabatannya dengan Raja Tano.

Dalam struktur sosial masyarakat, Raja Tano memiliki kedudukan yang paling tinggi. Dalam tatanan rumah tinggal di kampung, rumah Raja Tano berada di tengah-tengah deret. Rumah tersebut juga ditandai dengan tipe arsitektur yang mempertahankan keaslian bentuk jabu bolon.
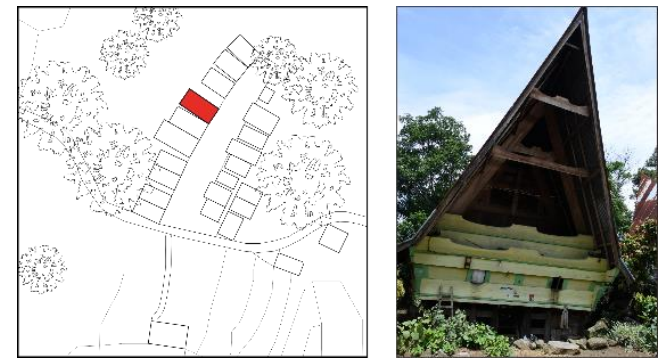

Figur 18. Rumah Raja Tano Kampung Lumban Godang
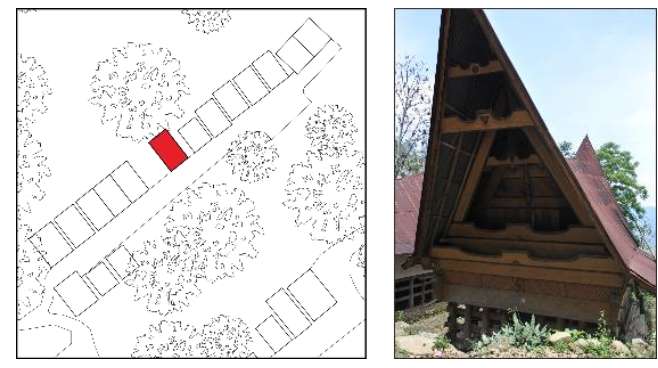

Figur 19. Rumah Raja Tano Kampung Sosor

Kampung di Desa Huta Ginjang tidak memiliki aturan atau persyaratan khusus yang mengatur pembangunan bagi rumah marga-raja maupun marga-boru. Hal ini juga ditunjukkan melalui penataan rumah tinggal di Kampung Sosor yang tidak memiliki pola khusus. Posisi seluruh warga, baik marga-raja maupun marga-boru dalam pembangunan adalah sejajar dan 
tidak memiliki kedudukan khusus, sehingga dalam permukiman tidak ada hierarki antara rumah marga-raja dan rumah marga-boru.

Tidak adanya hierarki antara rumah marga-raja dan marga-boru menunjukan prinsip Dalihan na Tolu yang menjadi pegangan dalam bermasyarakat. Prinsip kekerabatan suku Batak Toba ini tidak sama dengan sistem kasta suku lain, yaitu tidak ada kelompok yang kedudukannya lebih tinggi, sehingga ketiga kelompok ini memiliki kedudukan yang sejajar. Hal demikian berlaku juga pada perletakan rumah tinggal di kampung di Desa Huta Ginjang, yaitu tidak ada penempatan khusus bagi marga-raja dan marga-boru.

Tipologi bangunan rumah tinggal di Desa Huta Ginjang tidak dapat membedakan rumah milik marga-raja dan rumah milik marga-boru. Perbedaan kelompok kekerabatan tidak ditunjukkan pada ciri-ciri fisik bangunannya.

\subsection{SKALA RUMAH TINGGAL}

Wujud fisik rumah tinggal dalam kampung di Desa Huta Ginjang bervariasi, mulai dari rumah tinggal yang masih mempertahankan arsitektur tradisionalnya, hingga rumah tinggal modern dengan atap. Rumah tradisional dibedakan menjadi 2 tipe, yaitu jabu bolon dan rumah angkola. Rumah modern dibedakan juga menjadi 2 tipe, yaitu rumah modern berbentuk panggung dan memiliki kolong dan rumah modern yang tidak lagi memiliki kolong.

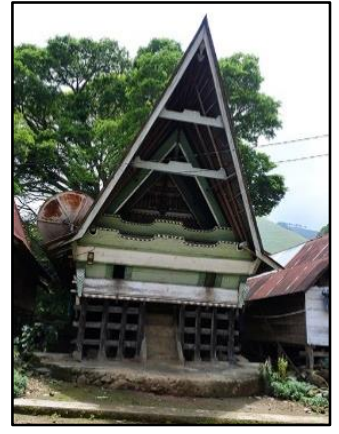

Figur 20. Jabu bolon

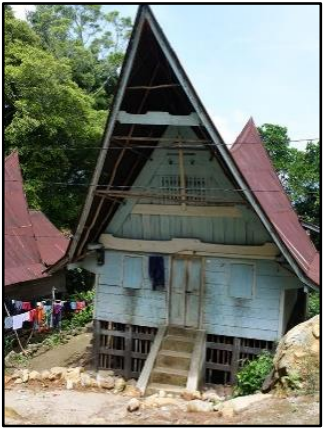

Figur 21. Rumah angkola

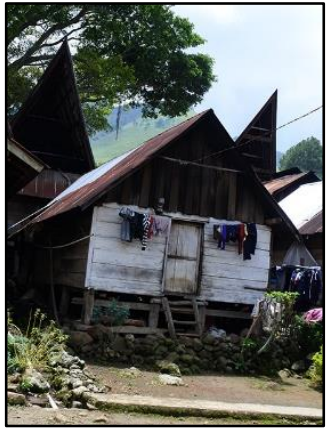

Figur 22. Rumah modern panggung

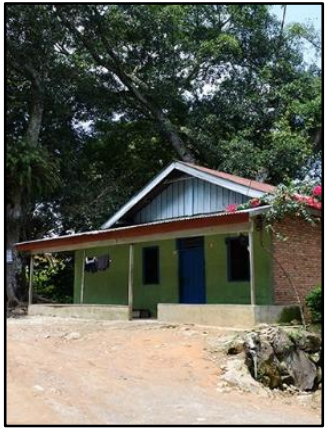

Figur 23. Rumah modern landed

Meskipun dengan bentuk fisik yang beragam, terdapat sebuah benang merah yang masih dipertahankan oleh bangunan-bangunan rumah tinggal yang ada di Desa Huta Ginjang, yaitu ruang vertikal yang dapat terbagi menjadi tiga bagian utama, yaitu: kepala, badan, dan kaki. Pembagian bangunan menjadi tiga bagian mengikuti aturan adat yang sudah diturunkan oleh leluhur yang terus berusaha dipertahankan.
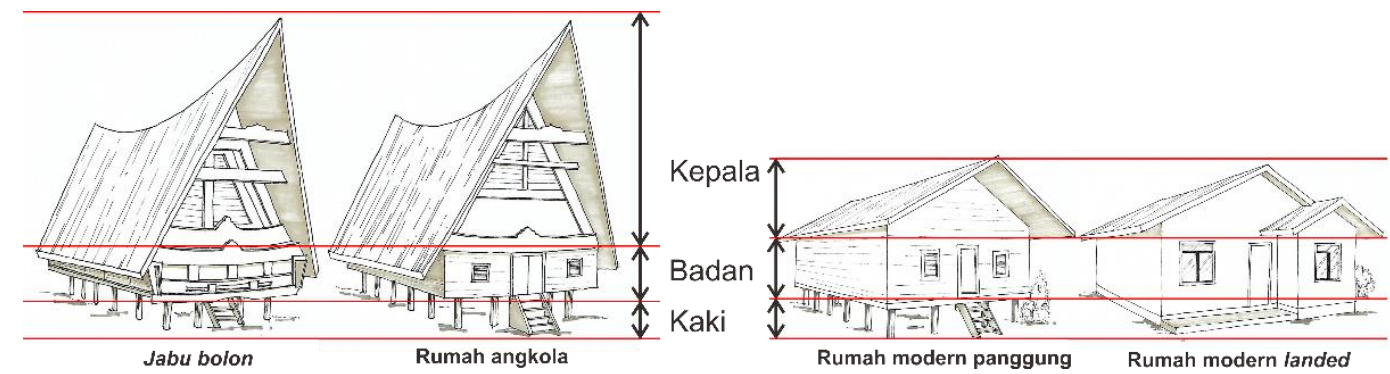

Figur 24. Pembagian ruang vertikal menjadi tiga bagian, yaitu: kepala, badan, dan kaki

Rumah tinggal tradisional Batak Toba memiliki ruang dalam berbentuk persegi panjang dan tidak bersekat. Ruang dalam rumah tradisional diorganisasikan menjadi beberapa area berdasarkan kelompok-kelompok hubungan kekerabatan Batak Toba. Keempat sudut dalam 
rumah diperuntukkan masing-masing bagi komponen-komponen dalam Dalihan na Tolu, yaitu: pemilik rumah, hula-hula, dongan tubu, dan boru. Rumah tradisional pada masa lampau dapat dihuni hingga delapan keluarga inti.

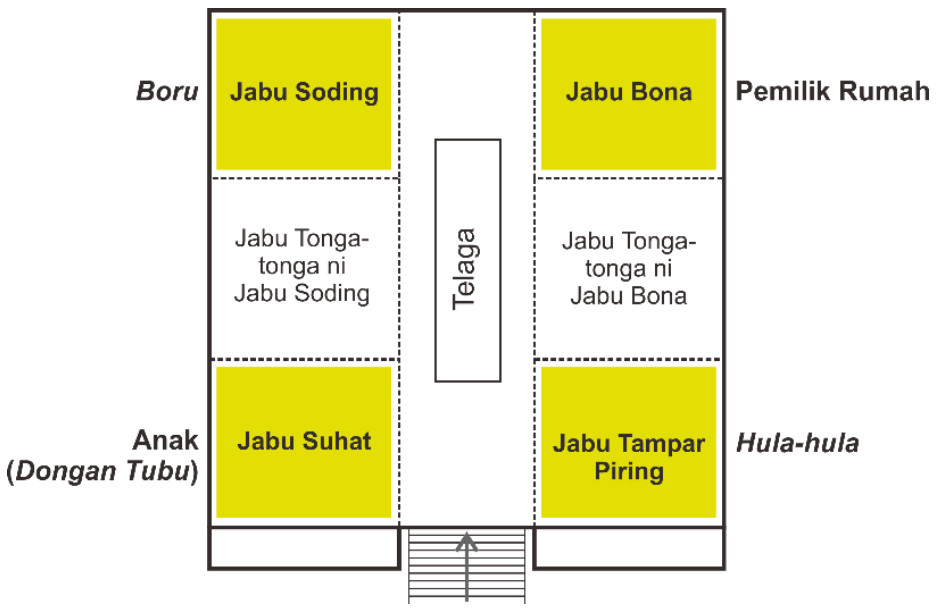

Figur 25. Pembagian dalam rumah tradisional menurut Dalihan na Tolu

(Sumber: Boer, 1920)

Pusat aktivitas dalam rumah tinggal tradisional berada di bagian tengah rumah. Ruang yang disebut telaga ini berada di bagian yang terlihat langsung dari arah pintu masuk rumah, dan memisahkan sisi kanan dan sisi kiri dalam rumah. Ruang ini merupakan ruang komunal yang dapat digunakan oleh seluruh penghuni rumah, dimanfaatkan oleh para penghuni untuk berkumpul dan berdiskusi. Pada ruang tengah dalam rumah, terdapat juga dapur atau sondi yang digunakan bersama oleh penghuni rumah.

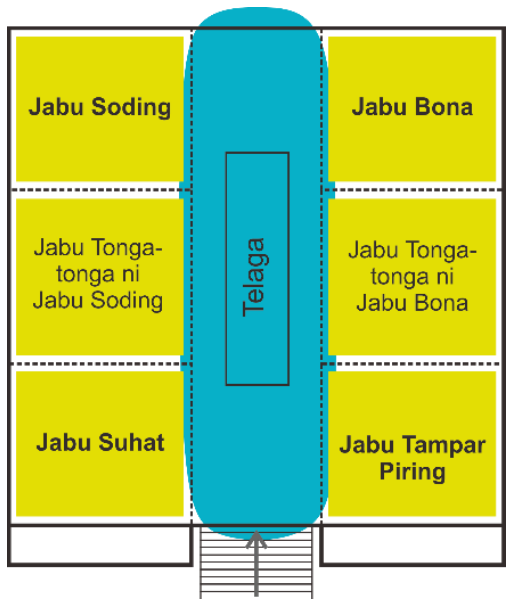

Figur 26. Ruang tengah sebagai pusat aktivitas dalam rumah tinggal tradisional

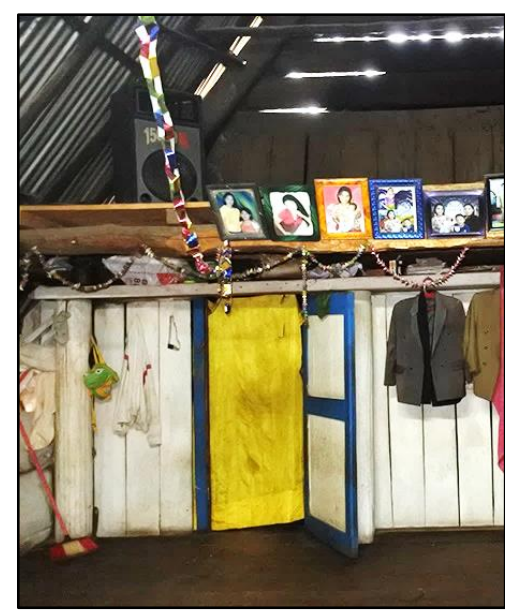

Figur 27. Ruang tengah rumah tradisional

Saat ini, rumah tinggal tradisional Batak Toba dihuni oleh sebuah keluarga inti dengan anggota keluarga berjumlah empat sampai enam orang. Meskipun ruang dalamnya tetap dipertahankan tanpa sekat, pemanfaatan ruang dalam tidak lagi mengikuti tradisi yang sudah digunakan sejak zaman nenek moyang.

Sebagian rumah tinggal dalam kampung di Desa Huta Ginjang sudah memiliki arsitektur yang lebih modern. Bentuk denah menjadi lebih kompleks dan ruang dalamnya sudah didesain dengan sekat atau dinding dalam. Rumah modern dihuni oleh satu keluarga batih dengan anggota keluar berjumlah empat hingga enam orang. 

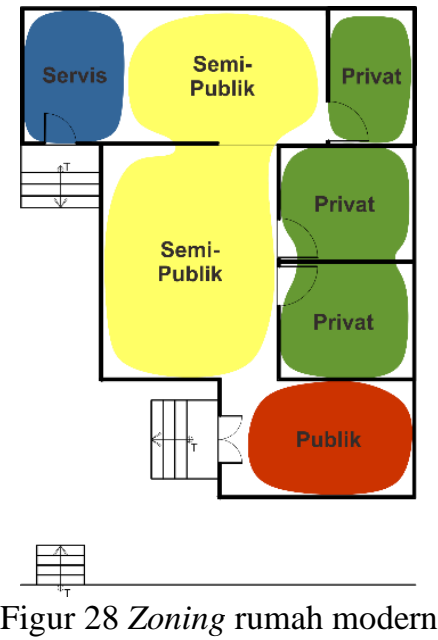

Pembagian ruang dalam rumah tinggal berdasarkan kebutugan fungsional, yaitu terdiri atas: ruang tamu, ruang keluarga, kamar tidur, ruang makan, dapur, dan kamar mandi. Penataan ruang dalam tidak lagi didasarkan pada hubungan kekerabatan, mengingat rumah tinggal dibangun untuk memenuhi kebutuhan satu keluarga inti saja. Zoning ruang dalam rumah tinggal sudah fungsional dengan pengelompokan ruang, yaitu: publik, semi privat, dan privat, sesuai dengan pemahaman modern yang masuk ke dalam masyarakat. Interaksi sosial antar penghuni rumah sebagian besar dilakukan di ruang keluarga dan ruang makan.

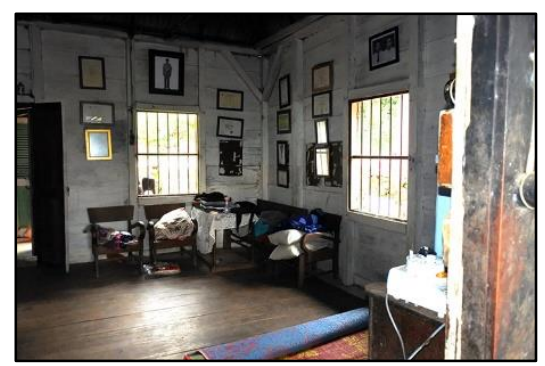

Figur 29. Ruang keluarga pada rumah modern

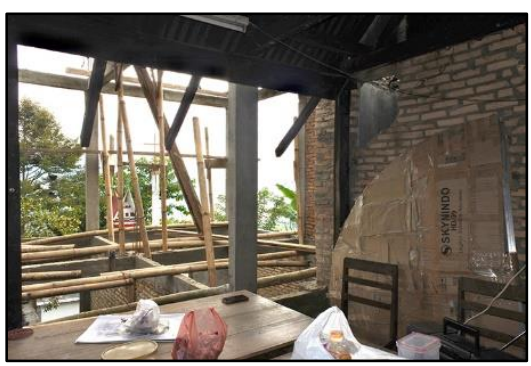

Figur 30. Ruang makan pada rumah modern

\section{KESIMPULAN}

\subsection{TATANAN FISIK SPASIAL PERMUKIMAN YANG TERBENTUK AKIBAT HUBUNGAN KEKERABATAN BATAK TOBA}

Pada skala desa, hubungan kekerabatan antar kampung terlihat melalui derajat kedekatan (proximity) antara sebuah kampung terhadap kampung induknya. Semakin dekat jarak antara kampung dengan kampung induk, semakin kuat atau erat hubungan kekerabatannya.

Pada skala kampung, rumah tinggal pertama yang menjadi titik awal pembangunan di kampung memiliki posisi di tengah deret. Rumah pertama ini merupakan rumah pemimpin adat di setiap kampung, bergelar Raja Tano, yang merupakan tokoh yang paling dihormati oleh masyarakat adat Batak Toba. Susunan rumah tinggal di kampung tidak memiliki perletakan khusus, baik milik marga-raja maupun milik marga-boru. Hal ini menggambarkan sistem kekerabatan Batak Toba tidak memiliki hierarki antar golongannya. Tipologi bangunan di kampung suku Batak Toba secara khusus tidak menunjukkan perbedaan antar komponen dalam sistem kekerabatan melalui bentuk fisiknya. Pada setiap kampung Batak Toba, halaman kampung berfungsi sebagai pusat aktivitas warga, memiliki kapasitas besar yang cukup untuk menampung kegiatan adat yang melibatkan seluruh warga. 
Pada skala rumah tinggal, pengaruh kekerabatan dapat dilihat pada pembagian ruang dalam rumah tradisional. Pengaruh kekerabatan ini sudah tidak lagi berlaku pada pembagian ruang dalam rumah tinggal modern.

\subsection{RELASI TATANAN FISIK SPASIAL PERMUKIMAN DENGAN SISTEM MARGA}

Sebuah permukiman Batak Toba pada umumnya dihuni oleh sebuah keluarga luas, ditandai dengan adanya satu marga yang lebih dominan dibandingkan marga lainnya. Di antara warga dengan marga yang sama, terdapat satu tokoh yang memiliki status sosial yang paling tinggi sehingga dihormati dan dituakan oleh warga kampung lainnya, yaitu pendiri kampung bergelar Raja Tano.

Dalam tatanan permukiman tradisional Batak Toba, rumah Raja Tano berada di tengahtengah deret. Hal ini disebabkan rumah tersebut merupakan rumah pertama yang dibangun, dan pembangunan selanjutnya bergerak dari tengah menuju pinggir kanan dan kiri. Rumah Raja Tano juga ditandai dengan wujud arsitektur yang paling tradisional dibandingkan wujud arsitektur rumah tinggal lainnya.

\subsection{RELASI TATANAN FISIK SPASIAL PERMUKIMAN DENGAN SISTEM DALIHAN NA TOLU}

Penataan rumah tinggal di permukiman Batak Toba tidak memiliki syarat perletakan khusus bagi rumah milik marga-raja dan marga-boru. Keberadaan marga-raja dan margaboru di kampung Batak Toba merupakan konsekuensi dari sistem kemasyarakatan Dalihan na Tolu. Rumah milik marga-raja dan marga-boru tatanannya tidak beraturan, menunjukkan tidak adanya hierarki dalam hubungan kekerabatan masyarakat Batak Toba.

Fenomena tatanan rumah tinggal di permukiman Batak Toba memperkuat prinsip kekerabatan Dalihan na Tolu. Dalam kekerabatan Dalihan na Tolu, tidak ada hierarki di antara ketiga komponen dalam masyarakat, yaitu hula-hula, dongan tubu, dan boru. Sesuai dengan analogi 'tungku tiga kaki', posisi ketiga kaki dalam tungku haruslah seimbang. Apabila ada satu komponen yang lebih tinggi dibandingkan komponen lainnya, maka kedudukan dalam masyarakat menjadi tidak seimbang.

Sistem kemasyarakatan Dalihan na Tolu juga diterapkan pada organisasi ruang dalam pada rumah tinggal tradisional. Ruang dalam terbagi menjadi beberapa wilayah yang diperuntukkan bagi komponen-komponen dalam kekerabatan Batak Toba, yaitu pemilik rumah, hula-hula, dongan tubu, dan boru. Aplikasi sistem kekerabatan Dalihan na Tolu dalam organisasi ruang dalam rumah tinggal saat ini sudah mulai ditinggalkan karena perubahan jumlah dan kebutuhan ruang penghuni rumah.

\subsection{PENGARUH MODERNISASI TERHADAP PERKEMBANGAN ARSITEKTUR PERMUKIMAN SUKU BATAK TOBA}

Pengaruh masuknya budaya modern dalam permukiman suku Batak Toba dapat dilihat dari penggunaan bahan bangunan, teknologi bangunan, dan wujud fisik rumah tinggal. Inovasi di bidang bahan bangunan menyediakan material sintetis yang dapat diproduksi secara massal, seperti batu bata, semen, dan seng, meninggalkan penggunaan material alami. Teknologi bangunan yang masuk ke dalam permukiman tradisional juga memungkinkan digunakannya sistem konstruksi baru, seperti paku menggantikan konstruksi tradisional ikat dan pasak. Teknologi bangunan pun menyebabkan rumah tinggal yang baru memiliki konstruksi pintu dan jendela.

Pembangunan yang baru sudah banyak meninggalkan tradisi atau pakem yang diturunkan oleh leluhur. Wujud fisik rumah tinggal di permukiman pun berangsur semakin modern. Tampilan yang modern terlihat pada bentuk atap bangunan, semula berupa atap pelana 
yang tinggi dan melengkung yang memiliki makna spiritual bagi masyarakat, berangsur semakin sederhana dan semakin kecil melambangkan efisiensi dan efektivitas. Denah bangunan yang sebelumnya berbentuk persegi panjang dan tidak bersekat, berangsur semakin kompleks dengan adisi dan substraksi bentuk. Hal ini dipengaruhi nilai dan budaya modern yang masuk dalam kehidupan masyarakat di permukiman Batak Toba.

Faktor yang mempengaruhi masuknya modernisasi ke dalam permukiman tradisional suku Batak Toba adalah masuknya pendatang yang membawa kebudayaan sendiri. Adanya warga kampung yang keluar dan mengunjungi daerah lain di luar wilayah kebudayaan Batak Toba, seperti adanya anggota keluarga yang merantau dan kembali dengan membawa pemikiran, gagasan, dan ide yang berbeda dari kebudayaan Batak Toba. Kemajuan teknologi, khususnya teknologi komunikasi dan transportasi, menjadi katalisator yang mempercepat pembangunan, termasuk di bidang arsitektur.

Dalam tatanan permukiman tradisional Batak Toba, pengaruh modernisasi yang paling besar dapat terlihat pada bangunan rumah tinggal yang letaknya di pinggir kampung. Semakin pinggir letak rumah dalam deret kampung, semakin modern juga wujud fisiknya. Hal tersebut disebabkan karena rumah-rumah yang letaknya di pinggir kampung dibangun lebih akhir.

\subsection{PENUTUP}

Tradisi permukiman tradisional Batak Toba di Desa Huta Ginjang sebaiknya tetap dipertahankan dan dilestarikan, khususnya bagi pembangunan di masa mendatang. Tatanan permukiman yang berbanjar dua dan saling berhadapan mengapit sebuah halaman luas sebaiknya tetap dipertahankan sebagaimana aturan-aturannya telah diwariskan oleh leluhur. Rumah tinggal tradisional yang ada di permukiman sebaiknya terus dilestarikan dengan mempertahankan keaslian bentuk dan tampilannya. Pelestarian terhadap tatanan fisik spasial permukiman tradisional Batak Toba ini dapat dijadikan sebagai objek wisata budaya dan berfungsi untuk memperluas wawasan arsitektur.

Kebudayaan, tatanan sosial masyarakat, dan arsitektur tradisional adalah kearifan lokal yang perlu dilestarikan karena merupakan identitas budaya lokal. Hendaknya globalisasi, modernisasi, dan perkembangan teknologi tidak menghilangkannya. Bahkan, kekayaan budaya ini sebaiknya dijadikan objek wisata budaya yang terus dipertahankan.

\section{DAFTAR PUSTAKA}

DE BOER, D.W. 1920. Het Toba Bataksche Huis. (Dalam Sargeant, G.T. \& Saleh, R., Traditional Buildings of Indonesia Volume I: Batak Toba. Bandung: United Nations - Regional Housing Centre - Ecafe. hal. 31-41.)

DOMENIG, G. 2003. Consequences of Functional Change: Granaries, Granary-dwellings, and Houses of the Toba Batak. (Dalam Schefold, R., Domenig, G., \& Nas, Peter (Eds.), Houses Volume I: Tradition and Transformation in Vernacular Architecture. Singapore: Singapore University Press. hal. 61-97.)

HENDRIX, John. 2012. Architecture as the Psyche of a Culture. (Dalam Emmons, Paul., Hendrix, John., \& Lomholt, Jane (Eds.), The Cultural Role of Architecture. Oxon: Routledge. Hal. 208216.)

KOENTJARANINGRAT. 1996. Pengantar Ilmu Antropologi: Jilid I. Jakarta: Rineka Cipta.

NAPITUPULU, S.P., d.k.k. 1986. Arsitektur Tradisional Daerah Sumatera Utara. Jakarta: Departemen Pendidikan dan Kebudayaan.

NORBERG-SCHULZ, Christian. 1963. Intentions in Architecture. London: Allen \& Unwin Ltd.

RAPOPORT, Amos. 1969. House Form and Culture. Englewood Cliffs, N.J.: Prentice-Hall, Inc.

SANGTI, Batara. 1978. Sejarah Batak. Balige: Karl Sianipar Company.

SARGEANT, G.T. \& SALEH, R. 1973. Traditional Buildings of Indonesia Volume I: Batak Toba. Bandung: United Nations - Regional Housing Centre - Ecafe. 
SCHNEIDER, David M. 1972. What is Kinship All About? (Dalam Parkin, Robert \& Stone, Linda (Eds.), Kinship and Family, Boston: Blackwell Publishing. hal. 257-274.)

SIMANJUNTAK, Bongaran Antonius. 2006. Struktur Sosial dan Sistem Politik Batak Toba Hingga 1945. Jakarta: Yayasan Obor Indonesia.

SITUMORANG, Sitor. 2009. Toba Na Sae. Jakarta: Komunitas Bambu.

SOEROTO, Myrtha. 2003. Dari Arsitektur Tradisional Menuju Arsitektur Indonesia. Jakarta: Ghalia Indonesia. 